\title{
PREVALENCE OF PHONOLOGICAL ARTICULATION DISORDERS IN PRESCHOOL CHILDREN IN THE CITY OF SKOPJE
}

\author{
Evgenija Grigorova $^{1}$, Gordana Ristovska ${ }^{2}$, Nada Pop Jordanova ${ }^{3}$ \\ ${ }^{1}$ Public Health Doctoral Studies, Faculty of Medicine, Ss. Cyril and Methodius University, Skopje, RN Macedonia \\ ${ }^{2}$ Institute of public health of Republic of North Macedonia, Skopje, RN Macedonia \\ ${ }^{3}$ Macedonian Academy of Sciences and Arts, Skopje, RN Macedonia
}

Corresponding author: Evgenija Grigorova email: evgeni4e@yahoo.com

\section{ABSTRACT}

Introduction: Speech communication is a complex process based on the function of the central nervous system, and also on the speech mechanisms conditioned and controlled by auditory perception, verbal memory, intellectual activity and peripheral speech apparatus.

The aim of this study was to determine the prevalence of the most common phonological articulation disorders in preschool children, from 4-6 years old.

Materials and methods: A cross-sectional study was conducted during 2018, on a representative sample of 550 preschool children aged 4 - 6 years, who attend preschool institutions-kindergartens in the city of Skopje. The study used standardized articulation tests: The Global Articulation Test (GAT) and the Triple Test (vocals, plasia, affricative, fricative, nasal, and lateral), and a questionnaire filled out by a social worker at the kindergarten about the socioeconomic status and the child's health condition.

Results: Using GAT, we found that 260 (47.3\%) children didn't manifest any phonological articulation disorders, but $290(52.7 \%)$ had disorders. The analysis of gender-based data showed a higher percentage of speech disorders in $57 \%$ of boys and $46.9 \%$ of girls. The highest percentage of speech disorder is sigmatism with $24.5 \%$ in boys and $20.4 \%$ in girls, rhotacismus was found in $17.8 \%$ in boys and $16.5 \%$ in girls. Lambdacism with $8.3 \%$ was found in boys and $4.2 \%$ in girls. A mixed form (sigmatism, rotacism, and lambdacism) was also found in $2.4 \%$ of boys and $3.5 \%$ of girls.

Conclusions: The calculated prevalence of phonological articulation disorders in preschool children aged 4-6 years is $52.7 \%$, $(57.9 \%$ in boys and $46.9 \%$ in girls), or every second child in kindergarten has some form of speech disorder. These findings indicate that the treatment of speech disorders should begin in the appropriate services as soon as possible, because the early detection and treatment of speech disorders enable child's normal intellectual development. The treatment should be started in the preschool period, to allow the start of the educational process without any speech problems.

Keywords: speech disorders, preschool children, cross-sectional study, global articulation test, triple test 


\section{INTRODUCTION}

Nowadays, many means of communication are available, but, without doubt, speech is the most beautiful, the most suggestive means by which person's thoughts express desires, emotions and ideas. In children, the first vocal elements appear related to the intonation and rhythm of the mother's speech, through the vocal play, through which they later upgrade their voices. In the adult world the child is engaged through speech, in a way that overcomes the knowledge of the previous generations, and as a coded form by acquiring new knowledge through verbalization and affective experience of the personality. The speech base should be ready at the age of three, but that does not mean that the child pronounces all the sounds correctly. Further, speech develops in such a way that the child has adopted what is the most basic and necessary for communication with the environment. The first words contain occlusions, both labial and dental, and their nasal variants. Speech, as the basis of the human communication, is a complex psychophysical process. Certain intellectual level, emotional capacity and instrumental skills are necessary for the realization of the speech [1].

Language can be learned by listening and trying to repeat what is heard. Speech communication is a complex process based on the function of the central nervous system (CNS), as well as the language mechanisms which are conditioned and controlled by auditory perception, verbal memory, intellectual activity, but also by the peripheral speech apparatus. If some deviations from this integrated complex system of its perfect functioning appeared, speech disorders would occur. Assessment for speech therapy and rehabilitation is necessary at the moment when the type of speech disorder is determined. The damage may be in different level of expressions, greater or less, and can make communication difficult to the point of impossibility.

Speech language disorders can be classified in five basic types $[2,3]$ :

- Phonological-articulation disorders (dyslalia, stigmatism, rhotacism, lambdacisms, tethacism).

- Language disorders (alalia, developmental aphasia, childhood aphasia-loss of already formed speech in childhood conditioned by various mechanical, biological, and tumor diseases of the CNS.

- Speech and rhythm disorders
- Voice disorders (aphonia, dysphonia, omniphonia) and

- Reading and writing disorders.

The main etiological causes for speech disorders can be related to biological, organic, psychological and environmental factors. Regardless of the age, there is the possibility of life changes through public health interventions conducted by speech and language therapists. Investing in speech and language therapy interventions is a cost-effective measure that sets out the needs for people's communication, health and well-being in the first place [4].

It was calculated, that each pound invested in speech and language therapy for children with communication needs generates 6.4 pounds by increasing lifelong earnings, compared to each pound invested in autism therapy, which generates only 1.46 through savings over a lifetime [5].

The aim of this study was to determine the prevalence of the most common phonological articulation disorders in preschool children aged 4-6 years living in the city of Skopje, the biggest city and capital of North Macedonia.

\section{MATERIAL AND METHODS}

\section{Study design}

A cross-sectional study was conducted during 2018 on a sample of preschool children, aged $4-6$ years, who attend preschool institutions in the city of Skopje. According to the statistical yearbook in 2016, a total of 34,386 children were cared for in kindergartens in the Republic of North Macedonia. Based on that, we determined that the representative sample should consist of 550 children.

We used standardized articulation tests, such as the Global Articulation Test (GAT) [6] and the Triple Test (vocals, plasia, affricative, fricative, nasal, and lateral) [6]. At the same time, we applied a questionnaire that was filled in by the social workers in the kindergartens on the child's socio-economic status and health condition.

Test data and queries are entered and databases are formed in the Excel document. The statistical analysis of the formed statistical series consists of descriptive and analytical phase. The structure of the statistical series with attributive features is analyzed by determining the coefficients of relations, proportions and rates. The structure of statistical series with numerical features is analyzed by determining the 
measures of central tendency (average values - arithmetic average) and dispersion measures (standard deviation). The analysis of the relationship between two series with attributive variables, and testing of the differences between two attributive series, was done using nonparametric tests (Pearson Chi-square, Difference test).

\section{RESULTS}

In the cross-sectional study, we included 550 children from preschool institutions in Skopje. The average age of children was $5.2 \pm 0.5 \mathrm{~g}$, in the range of 4 to 7 years (Fig. 1). The largest percentage were children aged 5 to 6 years $-75.5 \%$, followed by children aged $\geq 6$ years $-16.9 \%$ and with $7.6 \%$ are children under 5 years of age.

The male gender is represented with $52.7 \%$, and the female gender with $47.3 \%$. The percentage difference is statistically insignificant for $p>0.05$ (Difference test, $p=0.0917$ ), the difference is due to coincidence in our sample, therefore it is a homogeneous group by gender.
In most of the children, $68.5 \%$ of the mothers and $74.2 \%$ of the fathers had higher education, followed by the respondents in which the mother had secondary education $(30.7 \%)$ and the father in $23.5 \%$.

The distribution of participants according to the parental employment showed that $83.3 \%$ of participant's mothers and $88.9 \%$ of the fathers were employed. Unemployed were only $9.3 \%$ of the fathers, and $16.4 \%$ of the mothers.

The analysis of the disorder history showed that 519 children $(94.4 \%)$ didn't have any disease, and $31(5.6 \%)$ children were diagnosed with some disease. Concerning the type of disease, in $54.8 \%$ of the participants an autistic spectrum disorder was confirmed (statistically insignificant compared to other diseases, Difference test, $p=0.0727$ ), in 32.2\% asthma was registered, in $6.4 \%$ Diabetes mellitus (DM) type 1 was confirmed, hearing impairment in one child and jaw deformity in one child. (Table 1).

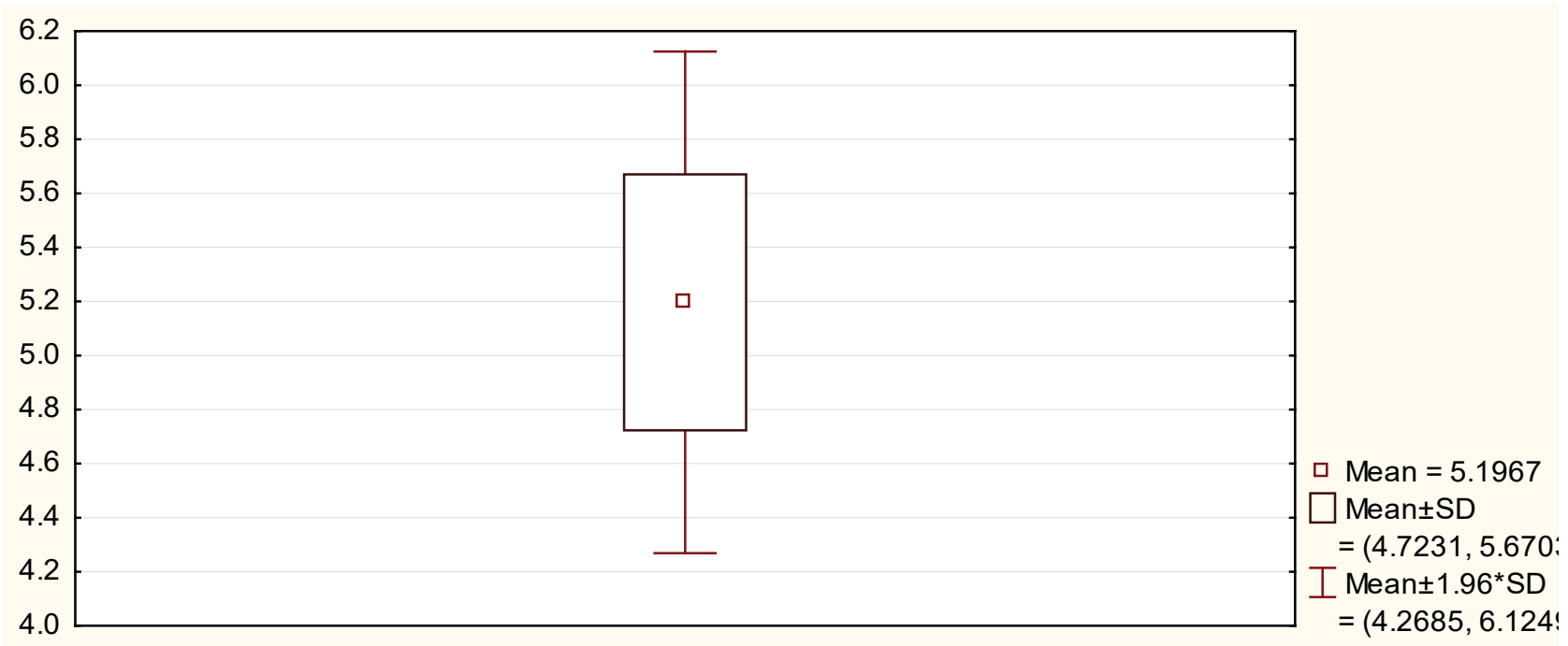

Figure 1. Average age of participants in the study

Table 1. Analysis of disease diagnosed in the participants

Distribution of examinees according to the family number showed, that $12(2.2 \%)$ children lived with one parent, while $97.8 \%$ of them lived with two parents. More than half of the examinees $(56.4 \%)$ live in a family of 4 members, $26.9 \%$ in a family with 3 members, $15.3 \%$ in a family with more than 5 members and 5 children in a family of only 2 members.

\begin{tabular}{|c|c|c|c|c|c|}
\hline & $\begin{array}{l}\dot{\bar{D}} \\
\text { है } \\
\text { हे }\end{array}$ & $\partial^{0}$ & 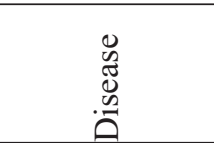 & $\begin{array}{l}\dot{\bar{D}} \\
\bar{E} \\
\text { Z }\end{array}$ & $a^{0}$ \\
\hline $\begin{array}{l}\text { No } \\
\text { disease }\end{array}$ & 519 & 94.4 & & & \\
\hline \multirow{5}{*}{$\begin{array}{l}\text { With } \\
\text { disease }\end{array}$} & \multirow{5}{*}{31} & \multirow{5}{*}{5.6} & Autism & 10 & 54.8 \\
\hline & & & jaw deformity & 1 & 3.2 \\
\hline & & & DM type 1 & 2 & 6.4 \\
\hline & & & $\begin{array}{l}\text { hearing } \\
\text { impairment }\end{array}$ & 1 & 3.2 \\
\hline & & & Asthma & 17 & 32.2 \\
\hline
\end{tabular}




\section{Global articulation test}

The results obtained with the global articulation test GAT showed that $260(47.3 \%)$ children didn't have speech disorders, and 290 (52.7\%) children had some form of speech disorder. Gender analysis has shown bigger percentage in boys with speech disorders $57 \%$, versus $46.9 \%$ in girls. The difference between boys and girls was statistically significant (Pearson Chi-square: 6.66463, df=1, $\mathrm{p}=.009836)$.

Table 2. Gender data analysis for speech disorders identified with GAT

\begin{tabular}{|c||c|c||c|c||}
\hline \multirow{2}{*}{ gender } & \multicolumn{2}{|c|}{ boys } & \multicolumn{2}{c|}{ girls } \\
\cline { 2 - 5 } & number & $\%$ & number & $\%$ \\
\hline \hline No disorders & 122 & 42.1 & 138 & 53.1 \\
\hline \hline With disorders & 168 & 57.9 & 122 & 46.9 \\
\hline total & 290 & 100.0 & 260 & 100.0 \\
\hline
\end{tabular}

Table 3. Gender analysis for speech disorders identified with triple test

\begin{tabular}{|l|c|c||c|c|}
\hline \multirow{2}{*}{ Gender } & \multicolumn{2}{|c||}{ boys } & \multicolumn{2}{c|}{ girls } \\
\cline { 2 - 5 } & number & $\%$ & number & $\%$ \\
\hline No disorders & 122 & 42.1 & 138 & 53.1 \\
\hline Sigmatism & 71 & 24.5 & 53 & 20.4 \\
\hline Rhotacism & 55 & 19.0 & 43 & 16.5 \\
\hline Lambdacisms & 24 & 8.3 & 11 & 4.2 \\
\hline Sigmatism-rhotacism & 6 & 2.1 & 4 & 1.5 \\
\hline Rhotacism-lambdacism & 3 & 1.0 & 1 & 0.4 \\
\hline Sigmatism-lambdacism & 2 & 0.7 & 1 & 0.4 \\
\hline $\begin{array}{l}\text { Stigmatism, rhotacism } \\
\text { and lambdacism }\end{array}$ & 7 & 2.4 & 9 & 3.5 \\
\hline Total & 290 & 100.0 & 260 & 100.0 \\
\hline
\end{tabular}

Having a number of $122(42.1 \%)$ boys and $138(53.1 \%)$ girls who didn't have speech disorders, the difference with the number of children with confirmed disorder was statistically significant for $p<0.05$ (Difference test, $p=0.0101$ ). Sigmatism was the most frequent in boys with $24.5 \%$ and $20.4 \%$ in girls, and the difference was statistically significant. Rhotacism was found in $17.8 \%$ of boys and in $16.5 \%$ of girls. Lambdacism was found in $8.3 \%$ of boys and in $4.2 \%$ of girls. The rest of the disorders were present in less than $2.0 \%$. The mixed form of stigmatism, rhotacism and lambdacisms was detected in $2.4 \%$ of the boys and in $3.5 \%$ of the girls.

\section{DISCUSSION}

This is the first cross-sectional study for determination of the most frequent phonological articulation disorders in preschool children at the age of 4-6 years, performed in 2018 on representative sample. This study confirmed that these disorders are present in a high percentage in preschool children and further action to decrease this number and reduce the consequences is needed.

Shimic M. (2015) performed the study in Zagreb on 101 subjects and found speech disorders in $40 \%$ of boys, and in $13 \%$ of girls. The most frequent disorders in girls were rhotacism, lambdacism, rhotacism and lambdacism, sigmatism, and in boys sigmatism; sigmatism and lambdacism; sigmatism and rhotacism; sigmatism, lambdacism and rhotacism. These findings are very similar with our findings [7].

Junuzovikj-Zunikj L and Ibrahimagikj A (2012) performed the study on 1,600 preschool children, at the age from 3-7 years and analyzed speech disorders. They found that sigmatism is the most frequent disorder and they concluded that prevalence of sigmatism decreased with chronological age of children [8].

Razmovska et al. (1997) studied speech disorders in slightly deaf children and found incorrect pronunciation of some voices, poor intonation of speech, especially in high-frequency spectrum voices ( $\mathrm{S}-\mathrm{Z}-\mathrm{C}$ rarely the sounds $\mathrm{Sh}-\mathrm{Zh}$ ). The sigmatism is the most pronounced as a consequence of the deafness in the occlusal (addental) sigmatism where the sounds $\mathrm{C}$ and $\mathrm{Z}$ lose the screaming sound and get a certain resemblance to the sounds $\mathrm{T}$ and $\mathrm{D}(\mathrm{Ts}, \mathrm{Tz})$ [9].

Stevovikj-Otasevikj J. (2016) in her doctoral dissertation conducted in Belgrade, with 60 participants, divided the examinees in two groups: an experimental group of 30 children with already diagnosed expressive speech disorder and a control group of 30 children with well-developed expressive speech. They concluded that the expressive speech disorder is more prevalent among males (76.7\%), compared to females (23.3\%). Differentiation of visual lateralization is worse in children with expressive speech disorder compared to children without expressive speech disorder. Auditory discrimination of voices (phonemic hearing) is better in children without the presence of expressive speech disorder, compared to children with expressive speech disorder [10].

The articulation is conditioned by several factors, but for the clear pronunciation of the voices, the anatomical and functional role of the speech organs is of special importance, concludes Georgievska-Janceska (2012). The changes in the orofacial area contribute to a clear and distinct 
pronunciation of voices. Depending on the severity and type of malformation of the speech organs, the pronunciation of a certain group of voices may be endangered, among which the most common are disorders in the pronunciation of fricatives, sonants, affricates and plosives [11].

Poposka A. (2009) used four relevant tests: global articulation test, articulation test, articulatory test for analytical assessment of phonological-articulatory deviations and test for speech intelligibility in study performed on 35 children diagnosed with early dysphasia, as well as a control group of 35 children with normal speech development. Children with developmental dysphasia have on average 20 accepted sounds, the most common voice location is the medial, while the most common type of voice deviation is substitution. The analytical approach in the assessing voice quality in verbal and vocabulary context proved the deviation from the physiology of pronunciation by more than one degree, which in turn occurs as a consequence of poor auditory memory, poor auditory discrimination, poor phonological awareness and inelasticity of peripheral speech organ [12].

Poposka A. and Filipova S. (2010) used two tests in their study comprising 71 subjects aged between 6 and 8 years, 35 subjects with developmental dysphasia and 36 subjects with dyslalia. The first test is a global articulatory test and it provides a good detection procedure for phonological articulatory disorders, while the second test is an analytical assessment of the articulatory and acoustic characteristics of damaged voices. They concluded that distortion-type voice impairment was more common in children with dyslalia, while substitution was more common in children with developmental dysphasia. In children with dyslalia, the voices from the fricative group are the most often damaged, while in children with developmental dysphasia, there are voice deviations in almost all voice groups. In both groups, a deviation in the articulation of the voices due to the wrong place of voice formation was confirmed[13].

McLeod S. and Harrison L. J. (2009) conducted a longitudinal study of 4,983 children (aged 4-5 years) in Australia, using interviews and parent questionnaires, teacher questionnaires, and direct assessment. Direct assessment confirmed that $13.0 \%$ of children had 1-2 SDs below the mean of the adapted Peabody Picture Vocabulary Test -III, and another 1.7\% had > 2 SDs below average. The results of parents and teachers were significantly corelated with the results obtained through direct assessment. They concluded that several indicators of speech and language disorders in various contexts have confirmed the high prevalence of this condition in early childhood and the simultaneous need for services of a speech therapist / special educator [14].

Norbury et al. (2016) find that $7.6 \%$ of children, which means two children in each class with 30 students actually start school with speech impairments, and $2.3 \%$ of the children start school with developmental disabilities in speech and another pathological condition. The overall estimate of the prevalence of the language disorder population is $9.92 \%(95 \%$ CI $7.38,13.20)$. The prevalence of language disorder from unknown origin is $7.58 \%(95 \%$ CI $5.33,10.66)$, while the prevalence of language impairment associated with intellectual disability and / or existing medical diagnosis is $2.34 \%(95 \%$ CI $1.40,3.91)$. Children with language disorders show an increase in certain social, emotional and behavioral problems compared to their peers, and $88 \%$ did not make the expected academic progress [15].

Karevska A. and Trajkovski V. in their study conducted in 2005 concluded that the etiology of speech impairments is diverse and complex, speech impairments most often occur in male respondents, mental retardation is associated with speech impairments in favor of syndromic etiology, orthodontic examination showed that any anomaly has influence on speech and leads alone or in combination with other etiological factors to speech impairment, and genetic factors play an important role in the occurrence of speech impairments [16].

Angst OVM et al. (2015) in their paper on the prevalence of phonological articulatory disorders in children attending kindergarten and going to school, concluded that the most common disorder was the disorder of orofacial myology (31.30\%), followed by speech disorder $(21.37 \%)$, and language disorder $(4.58 \%)$. The analyzed sample showed a high prevalence of speech disorders. These results indicate the importance of the role of the speech therapist in schools for the correction of pathological speech. They found that the uniformity of the sample did not cause a link between speech disorders and social factors, which indicates the need to conduct research with more diverse samples [17].

Demerdzieva and Pop-Jordanova [18] found in their study that $43.48 \%$ of children in the third year, $35.71 \%$ of children in the fourth year and 
$45.45 \%$ in the fifth year had speech disorders. In their evaluated sample, $65.81 \%$ of children didn't speak at the time during the first assessment, although in some children at the age of 3-5 years speech therapy was started. Untreated speech and language delay can persist in $40 \%-60 \%$ of the children and these children are at a higher risk of social, emotional, behavioral, and cognitive problems in adulthood. The most concerning fact is the increased incidence of attention and social difficulties at later age, especially in teenage children, in whom speech and language impairments persist during 5 and half years of age have [19].

\section{CONCLUSION}

The prevalence of phonological articulation disorders in children aged 4-6 years was in general $52.7 \% ; 57 \%$ in boys and $46.9 \%$ in girls. The most common speech disorders were sigmatism, rhotacism, lambdacism. The influence and the connection of the socio-economic status of children and parents with the occurrence of phonological articulation disorders should be the subject of future research work, as well as the awareness of parents about speech disorders in their children and access to speech therapy services.

Speech disorders in preschool children are an important public health issue because these children, when they start at school, they will be a vulnerable group that requires not only speech-related intervention but also, in some cases, emotional and behavioral support. These findings indicate that the treatment of speech disorders should begin in appropriate services (speech therapy or special education and rehabilitation), because early detection and treatment of speech disorders gives the child more confidence to build the intellect. The treatment should begin while the child is in preschool, to allow the beginning of the educational process without speech and articulation disorders.

\section{REFERENCES}

1. Benc Stuka N. Poremecaj Izgovora. U D. Andresic, N. Benc Stuka N (ur.), Kako Dijete Govori? Razvoj govora i jezika, Najcesci poremecaji jezicno-govorne kombinacije djece predskolske dobi. Zagreb: Planet 2010: 19-27.
2. Јачова 3, Солтирова Е, Икономова С, Чичевска Н, Ѓ еоргиева Н. Предучилишно воспитание на децата со пречки во развојот - предуслов за успешно интегрирано образование. Дефектолошка теорија и практика 1996; 9-21.

3. Bleile KM. Manual of Articulation and Phonological Disorders: Infancy Through Adulthood. Canada: Delmar Learning 2004.

4. Evans N, Levinson S. The Myth of Language Universals: Language Diversity and Its Importance for Cognitive Science. Behavioral and Brain Science 2009; 32: 448-494.

5. Royal College of Speech and Language Therapists. An Economic Evaluation of Speech and Language Therapy. 2010. Available at: tinyurl. com/n2rc6jp

6. Kostic Đ. Vladisavljevic S. Popovic M. Testovi za Ispitivanja Govora i Jezika. Zavod za Udžbenike i Nastavna Sredstva, Beograd, 1983.

7. Shimic M. Uchestalost i Vrste Dislalija u Djece Pred Polazak u Shkolu. Sveuchilishte u Zagrebu 2015.

8. Juzunovik-Zunik L, Ibrahimagik A. Analysis of Errors in Children with Sigmatismus in the Bosnian/ Croatian/ Serbian Language. Journal of Special Education and Rehabilitation 2012; 13 (1-2): 95-107.

9. Размовска В, Степановска В, Неделковски Б. Раното Откривање на Сигматизмот како Последица на Лесната Наглувост. Дефектолошка теорија и практика 1997; 2: 105-106

10. Stevovic-Otasevic J. Prognostic Value of Neurophysiological and Neuropsychological Indicators in Detecting Risks of Speech Development in Preschool Children. Doctoral thesis at University of Belgrade 2016.

11. Јанческа Георгиевска Т. Ортодонските Аномалии и Изговорот на Гласови. Стоматолошки факултет 2012 [ Accesed 06.8.2019].

12. Попоска А. Атрикулативните Специфичности кај Децата со Развојна Дисфазија во Рана Училишна Возраст. Дефектолошка Теорија и Практика 2009; 10: 3-4.

13. Попоска A, Филипова С. Компаративна Анализа на Фонолошко- Артикулативните Растројства на Диференцијална Дијагноза. Дефектолошка Теорија и Практика 2010;11(12): 53-65.

14. McLeod S, Harisson LJ. Epidemology of Speech and Language Disorders in A Nationally Representative Sample of 4 to 5 Year Old Children. Journal of Speech Language and Hearing Research 2009; 52: 1231-1229.

15. Courtenay $\mathrm{N}$ et al. The Impact of Nonverbal Ability on Prevalence and Clinical Presentation of Language Disorder: Evidence From A Popu- 
lation Study. Journal of Child Psychology and Psychiatry 2016; 57(11): 1247-1257.

16. 16. Karevska A, Trajkovski V. Etiology of Speech Disorders in "Institute for Rehabilitation of Hearing, Speech and Voice"- Skopje., Journal of Special Education and Rehabilitation 2005; 6 (1-2): 27-34.

17. Angst OVM, Liberalesso PK, Wiethan MF, Mota BH. Prevalence of Speech-Language Disorders in Kindergarten Children of Public Schools and
The Social Indicators. Revista CEFAC 2015;17 (3): 453-459.

18. Demerdzieva A, Pop-Jordanova N. History information's are indispensable in developmental assessment of children. Contributions $\mathrm{Sec}$ of Med Sci 2020; XLI 1: 33-45.

19. 19. Snowling MJ, Bishop DV, Stothard SE et al. Psychosocial outcomes at 15 years of children with a preschool history of speech language impairment. J Child Psychol Psychiatry 2006; 47(8): 759-765.

\title{
Резиме
}

\section{ПРЕВАЛЕНЦИЈА НА ФОНОЛОШКО-АРТИКУЛАТИВНИ НАРУШУВАЊА КАЈ ПРЕТШКОЛСКИ ДЕЦА ВО ГРАД СКОПЈЕ}

\author{
Евгенија Григорова ${ }^{1}$, Гордана Ристовска ${ }^{2}$, Нада Поп-Јорданова ${ }^{3}$ \\ 1 Докторски студии по јавно здравство, Медицински ғакултет, Универзитет „Св. Кирил и Методиј“, \\ Скопје, РС Македонија \\ ${ }^{2}$ Институт за јавно здравје на РС Македонија, Скопје. \\ ${ }^{3}$ Македонска академија на науките и уметностите, Скопје, РСМакедонија
}

Вовед: Говорната комуникација е сложен процес, кој се темели на функцијата на централниот нервен систем, а исто така, и на говорните механизми условени и контролирани со аудитивна перцепција, вербално помнење, интелектуална активност и со периферниот говорен апарат.

Целта на студијата беше да се утврди преваленцијата на најчестите фонолошко-артикулативни нарушувања кај децата во предшколска возраст, од 4 до 6 години.

Материјал и методи: Студија на пресек е спроведена во текот на 2018 година на репрезентативен примерок од 550 деца на предшколска возраст, од 4 до 6 години, кои посетуваат предучилишни установи - детски градинки во градот Скопје. Во истражувањето се применети стандардизирани тестови за артикулација: Глобален артикулационен тест (ГАТ) и Тријажен тест (вокали, плозиви, африкати, фрикативи, назали и латерали), и прашалник што го пополни социјалниот работник во градинката за социоекономскиот статус на детето и за неговата здравствена состојба.

Резултати: Со примена на ГАТ утврдивме дека кај 260 (47,3 \%) деца не постои нарушување на говорот, додека кај 290 (52,7 \%) нарушување на говорот постои. Анализата на податоците според полот покажа повисок процент на нарушување на говорот кај машките деца 57 \%, а кај женските деца тој изнесува 46,9 \%. Во најголем процент застапена е говорната промена сигматизам со $24,5 \%$ кај машкиот пол и $20,4 \%$ кај женскиот пол, ротацизамот е застапен со $17,8 \%$ кај машкиот пол и со 16,5 \% кај женскиот пол. Ламбдацизам со 8,3 \% е застапен кај машкиот и co $4,2 \%$ кај женскиот пол. Застапена е и мешана форма (сигматизам, ротацизам и ламбдацизам) кај 2,4 \% од учесниците во студијата од машки пол и кај 3,5 \% кај женскиот пол.

Заклучоци: Преваленцијата на говорно-артикулативните нарушувања кај децата од 4 до 6 години изнесува $52,7 \%$, и тоа кај машките деца $57 \%$, а кај женските деца $-46,9 \%$ или секое второ дете во градинка има говорно нарушување. Овие наоди индицираат дека треба да се започне со третман на говорните нарушувања колку што е можно порано, затоа што раната детекција и третман ќе овозможат нормален интелектуален развој кај детето. Третманот треба да започне на претшколска возраст, за детето да го започне образовниот процес без говорни нарушувања.

Клучни зборови: говорни нарушувања, претшколски деца, студија на пресек, глобален артикулационен тест, тријажен тест 